\title{
The Development of Smart Flexibility Tools to Measure the Digital-Based Abilities
}

\author{
Ardhana Purnama Putra \\ Master Program in Sports Sciences \\ Yogyakarta State University \\ Yogyakarta, Indonesia \\ ardhanapputra@gmail.com
}

\author{
Siswantoyo \\ Faculty of Sports Sciences \\ Yogyakarta State University \\ Yogyakarta, Indonesia \\ siswantoyo@uny.ac.id
}

\begin{abstract}
- the purpose of sports cannot be separated from the tools used. Sport equipment are helping to achieve sports activities. Sport tools are very important for the continuity of sports activities, for instance physical fitness measuring devices, tools for supporting sport activities and many other functions. Sport facilities and equipments are very important for the development and achievement of sports globally. This research is motivated by the unavailability of equipments or sport facilities and infrastructure used in the learning of the subject in this case in the form of a flexible measuring device, even though the measuring instrument is needed because it is a component of physical fitness. Measurement of flexibility with manual and lack of standard tools obtained results, which are less accurate, valid, and maximal. In this fact, the researcher thinks to develop smart flexibility tools to measure digital based flexibility so that the development of sports equipment is more advanced and modern in accordance with the development of science and technology. This study aims to produce the digital-based flexibility meter to be more valid. This research is $R \& D$ research (Research and Development. The design of this research uses Borg \& Gall model. In the development procedure, there are ten steps. The research subjects are junior and senior high school students (Special Sports Class) in Yogyakarta. The results of this research is a set of digital-based smart flexibility tools that is easy to use, accurate, and simple to use and can be used for measurement in early age groups, adolescents, adults and for general.
\end{abstract}

\section{Keywords-smart flexibility, flexibility, digital}

\section{INTRODUCTION}

Sport is seen from the point of view of sport physiology is a series of organized and planned body movements that people do consciously to improve their functional abilities, in accordance with the purpose of exercising. One of the goals of sports is to make people move (human movement). In addition to sports in its development, sports can be done as entertaining activities, fun or done to improve achievement. If we put aside sport activities it is not impossible that our body condition is far from physical fitness. Physical fitness is one of the most important and vital things for us to be able to do daily activities. Physical fitness is purposed to improve people's work ability so that everything runs optimally as planned beforehand.
The government makes sport as the support for realizing of healthy Indonesian people and developing a sport culture in order to improve the quality of Indonesian people so that they have a good health. The purpose of sports cannot be separated from the tools used. Sport equipment are helping to achieve sports activities. Sport tools are very important for the continuity of sports activities, for instance physical fitness measuring devices, tools for supporting sport activities and many other functions. Sport facilities and equipments are very important for the development and achievement of sports globally [1]. Tools or media will not be separated from the technology developments because technology progress is one of the factors that contributes to renewal efforts.

In this age of globalization, science and technology are growing rapidly to support human life. Human needs increasingly are making people always innovate to develop it. The development of science and technology is also felt by sport people who have a positive impact marked by innovating tools, facilities and infrastructure used in the field of sports. Technology has many functions in the field of sports [2]. The expectation is that the innovation of technology in the field of sports can increase the effectiveness, efficiency, and accuracy in terms of education in school. Sports talent is not enough without technology intervention to achieve a higher level of precision. In this digital era, it needs a breakthrough for the development of digital devices in the field of sports in order to achieve something easily that has been expected together. The development of sport equipment is a success for sports people to make major changes in the field of sports to be more advanced.

In this modern and digital era, Technology is a thing that is not released in the daily life. In the developed countries, the achievements in the sport field are more advanced because they involve technology intervention. This phenomenon happens because of the effectiveness, efficiency and accuracy of modern technology is higher than the manual one. The Indonesian potential to develop technology in the field of sports is actually not inferior to other developed countries because Indonesia has many sports scientists whose abilities a re undoubted. So that the potential must be explored deeply for the sport advanced and to improve the quality in the teaching learning in school also to improve the achievements that can bring the name of the country to the world level. The new technology in this study is a smart flexibility tool to measure digital-based flexibility. 
It is determined by the part of the physical fitness that is very important and needed by the students in school because it is a basic physical ability of children that needs to be developed. The level of physical fitness had by each student is a result of the learning process carried out by the teacher at the school. Based on the observations, it is obtained that in fact in elementary schools, junior high schools, and senior high schools there have not been found the availability of sport equipments and facilities used in teaching learning, in this case in the form of flexibility measuring device. More specifically, the tools for measuring the flexibility have not been owned by some schools, even though the measuring device is needed because it is a component of physical fitness. During this time the learning process in the measurement of flexibility is still using manual sewing meters only which have many weaknesses.

The results of the interviews with five primary school teachers, five junior high school teachers, and five senior high school teachers in Sleman Regency found that the school did not have the tools to measure flexibility, so that it rarely did the flexibility measurements during the process of Teaching learning. One of the training teachers confirmed that the measurement of flexibility uses a less standard tool and it obtained results that were less accurate, valid, and maximal.

Based on the reality above, the researcher thinks to develop smart flexibility tools to measure digital-based flexibility so that the development of sports equipment is more advanced and modern in accordance with the development of science and technology. If this development is successful, it will greatly assist the training teacher in carrying out physical fitness tests, especially flexibility.

Along with the technology advance in the era of globalization, this should also be accompanied by the development of sport equipments, because these digital devices are still using manual tools that must be changed so that the tools used becomes more effective, efficient and accurate. So, it is expected that the development of this tool can improve the quality of teaching and learning in schools.

The problem solving above must be the solution for the problem faced by the development of smart flexibility tools to measure digital-based flexibility. It is expected that with the design of smart flexibility, tools can improve technology in the Yogyakarta State University and in the future, it can be developed to be more advanced and better so that science and technology in the field of sports can develop rapidly in accordance with its functions.

\section{LITERATURE}

\section{A. The nature of development}

Development has become a watchword and attraction in sport around the world. However, the governments, policy makers, and advocates often have an unattractive understanding of the development and role of sport in it [3]. Changes and technological innovations are very helpful and provide a significant increase in the quality and quality of the sport itself. Innovations that can be used specifically in terms of technology and facilities. A new study with potential to be developed, one of which is facilities and infrastructure [4].

\section{B. Tests and Measurements}

Tests is "a systematic method of gathering data for the purpose of making intra or inter-individual comparisons" [5]. Tests is a process that is carried out systematically to obtain quantitative quantities of a particular object by using a standard measuring instrument [6]. In line with this, also provides a definition of measurement, namely "measurement is concerned with the systematic collection, quantification, and ordering of information" [5].

\section{Physical fitness}

Physical fitness is the ability of the body to make adjustments (adaptation) to the physical exemption given to it (from daily work) without causing excessive fatigue [7].

\section{Flexibility}

Flexibility is the ability of joints to move freely [8]. Flexibility as one component of physical fitness is the ability to move the body or parts as wide as possible without joint tension and muscle injury [9].

\section{E. Digital Technology}

Mentioned by the KBBI, that technology is a scientific method that is used to achieve practical goals, and it is one of the applied knowledge. Next, it is also said that technology is an overall means to provide goods needed for the continuity and comfort of human life. From the statement of the Indonesian dictionary, it can be concluded that technology is a scientific method for practical purposes that can be useful the human needs and the convenience of human life.

\section{RESEARCH METHODS}

This study aims to produce a smart flexibility tool for measuring digital-based flexibility. The research conducted is a product development activity, so this type of research is research and development. Research and development is a research method used to produce a specific product design, effectiveness of test, validity of the design that has been made so that the product tested can be used by the public [10]. Producing certain products used by the research that is needs analysis and effectiveness tests are carried out so that the community can use products. As those are the steps to develop and fix an existing product, and can be accounted for [11]. The result of the research is used to design a product that have been tested in the field, evaluated, and refined. The result of the product is expected to be a product that is useful, have certain quality, effective, efficient, accurate, meets the standards and valid so as to facilitate physical fitness data retrieval, especially flexibility. There is also needs to develop a product improvement to keep up with this modern and alldigital era, because existing products are not in line with the current reality. In this case, the researcher developed a smart flexibility tool to measure digital-based flexibility. 


\section{A. Research procedure}

The development procedure is the step that must be taken to produce a product. In this study the researcher uses steps from Borg and Gall. According to Borg and Gall in the book conducting research and development there are ten steps that must be done, namely (1) research and data collection, (2) planning, (3) draft of development product, (4) initial field trials (small scale), (5) revising trial results, (6) field trials (large scale), (7) improving the results of field trials, (8) field implementation tests (product effectiveness testing), (9) final product improvement, (10) dissemination and implementation [11]. Basically the research and development procedure consists of two objectives, namely developing a product (development function) and testing the effectiveness of the product in achieving its objectives (validation function).

\section{B. Participant}

The research on the development of smart flexibility tools to measure digital-based flexibility was carried out on a small and large scale in one of junior and senior high school (the Special Class Sports) in Yogyakarta with a number of different subjects. And for the effectiveness test conducted in one of the elementary, junior and senior high school in Sleman Regency.

\section{Data Collection Instrument}

Data analysis techniques used in this study can be seen as follows:

TABle 1. DATA COLlection TeChNiQUES AND INSTRUMENTS

\begin{tabular}{|l|l|l|}
\hline No. & $\begin{array}{l}\text { Data Collection } \\
\text { Technique }\end{array}$ & \multicolumn{1}{c|}{$\begin{array}{c}\text { Data Collection } \\
\text { Instrument }\end{array}$} \\
\hline 1. & Questionnaire & $\begin{array}{l}\text { Blindness questionnaire } \\
\text { analysis sheet } \\
\text { Media expert validation } \\
\text { questionnaire sheet Expert material } \\
\text { questionnaire sheet Small-scale trial } \\
\text { questionnaire sheet Large-scale trial } \\
\text { questionnaire sheet }\end{array}$ \\
\hline 2. & Tests & Effectiveness test form \\
\hline
\end{tabular}

\section{Data Analysis Techniques}

Data analysis is the process of systematically searching and compiling data obtained from interviews, field notes, and other materials, so that they can be easily understood, and their findings can be informed to others. Data analysis is done by organizing data, describing it into units, synthesizing, arranging into patterns, choosing what is important and what will be learned, and making conclusions that can be shared to others [12].

Data analysis techniques in this study use qualitative and quantitative analysis. The process of qualitative data analysis is done by reducing data, namely the process of completion, simplification, focusing, dedication, and transformation of data [13]. Data reduction is done continuously starting from the beginning of data collection until completion.
After data reduction, the next data analysis activity is the presentation of the data and making conclusions.

Quantitative data analysis in this development is the management of data in this study using quantitative descriptive statistical analysis. This statistic serves to describe or present information so that the data obtained can draw conclusions. Data analysis techniques in this research and development are:

\section{Product Feasibility Analysis}

After the draft of the product is made, the next right is to analyze the draft of the smart flexibility product by referring to the data in the form of total scores obtained from the sum of the item scores provided by the expert. Products considered feasible to be tested with small scale or large scale quantitatively calculated scores achieve minimum standards of feasibility. The score obtained is first converted into percentage values using the following formula:

$$
\text { Assessment }=\frac{\text { the number of scores obtained }}{\text { maximum total score }} \times 100
$$

After the raw score is converted into a percentage value, then it is converted by using an assessment norm that refers to the benchmark reference assessment with the form of a score range as follows

TABle 2. THE SCORE RANGE

\begin{tabular}{|l|l|l|}
\hline No & $\begin{array}{c}\text { The Score } \\
\text { Range }(\boldsymbol{\%})\end{array}$ & $\begin{array}{c}\text { Categories Of } \\
\text { Feasibility }\end{array}$ \\
\hline 1 & $80 \%-100 \%$ & Very Feasible \\
\hline 2 & $70 \%-79 \%$ & feasible \\
\hline 3 & $60 \%-69 \%$ & Quite feasible \\
\hline 4 & $50 \%-59 \%$ & Less feasible \\
\hline 5 & $40 \%-49 \%$ & Not Feasible \\
\hline
\end{tabular}

The score range in the table was adopted from [14]. Whereas to analyze the effectiveness test results data is using t-test (dependent sample t-test) paired sample t-test using SPSS 21 for windows. The data from the application of SPSS 21 is translated into qualitative data that shows the feasibility of the product. The prerequisites that must be met before the t-test include the normality test (KolmogorovSmirnoff). The data obtained is categorized as normally distributed if the probability value is greater than 0.05 ( $p>$ $0.05)$.

\section{CONCLUSIONS}

Digital-based smart flexibility tools have been developed and have been tested for their feasibility and effectiveness as well as valid in measuring flexibility. Digitalbased smart flexibility tools have guidebooks in their usage procedures. The resulting product can automatically save the data when reducing it in the memory installed on the device. 


\section{REFERENCES}

[1] S. Onojohwevwo, E. Akarah et al. "Availability of Facilities and Equipment for Sports Administration at the Local Government Areas of Delta State, Nigeria". Academic Journal of Interdisciplinary Studies, 2015. Doi:10.5901/ajis.2015.v4n2p307.

[2] S. Loland, "Technology in Sport: Three Ideal-Typical Views and Their Implications". Journal of Sport Studies, 2003, vol. 2.

[3] H. Hartmann, S. Kwauk, "Sport and Development: An Overview, Critique, and Reconstruction". Journal of Sport and Social Issues, 2011. Doi: 10.1177/0193723511416986.

[4] A. Maksum, "Metodologi Penelitian dalam Penelitian". Surabaya: Unesa University Press, 2002.

[5] D. A. Payne, “Applied educational assessment, $2^{\text {nd }}$ edition". Belmont: Thomson Learning, 2003.

[6] Sridadi. “Teknik Pengukuran dan Penilaian”. Yogyakarta: Mitra Cendekia Press, 2007).

[7] Muhajir, "Pendidikan Jasmani Olahraga dan Kesehatan". Jakarta: Erlangga, 2007.

[8] D. P. Irianto, "Pedoman Praktis Berolahraga untuk Kebugaran dan Kesehatan”. Yogyakarta: Andi Offset, 2004

[9] Ismaryati, "Tes pengukuran olahraga". Surakarta: Sebelas Maret University Press, 2006.

[10] Sugiyono, "Metode Penelitian Kuantitatif Kualitatif dan R \& D". Bandung: Alfabeta, 2013.

[11] N. S. Sukmadinata, "Metode Penelitian Pendidikan". Bandung: PT Remaja Rosdakarya, 2015.

[12] Sugiyono, "Metode Penelitian Kuantitatif dan R \& D". Bandung: Alfabeta, 2010.

[13] S. Arikunto, "Prosedur penelitian: Suatu Pendekatan Praktik (Edisi Revisi)". Jakarta: Rineka Cipta, 2010.

[14] A. Sudjiono, "Pengantar evaluasi pendidikan". Jakarta: PT. Raja Grafindo Persada, 2011. 